\title{
Elemental profile of edible mushrooms from a forest near a major Romanian city
}

\author{
Andreea R. ZSIGMOND, ${ }^{1 *}$ Krisztina VARGA, ${ }^{1}$ Sándor HARANGI, ${ }^{2}$ \\ Edina BARANYAI, ${ }^{2}$ István URÁK ${ }^{1}$ \\ ${ }^{1}$ Sapientia Hungarian University of Transylvania, \\ Department of Environmental Science, 400193 Cluj-Napoca, Calea Turzii 4, Romania. \\ e-mail: zsigmond.andrea@kv.sapientia.ro, (*corresponding author) \\ ${ }^{2}$ University of Debrecen, Department of Inorganic and Analytical Chemistry, \\ 4032, December, Egyetem tér 1., Hungary
}

Manuscript received August 30, 2015; revised September 25, 2015; accepted September 28, 2015

\begin{abstract}
We determined the elemental profile of 16 edible mushroom species from the Făget Forest, near Cluj-Napoca, and of 12 species from the Apuseni Mountains. Oneway ANOVA showed no difference in the elemental content of mushrooms when the two regions were compared. Some species accumulated high amounts of trace elements, i.e. Boletus edulis (Ag, S, Zn), Macrolepiota procera $(\mathrm{Cu})$, Lactarius volemus $(\mathrm{Co})$, Russula emetica (Mn), Armillariella mellea, and Chantarellus cibarius (Cr). The cadmium content was the highest in the case of Leccinum scabrum and Boletus edulis. These two species presented elevated risk levels for all age-groups when they are consumed regularly.
\end{abstract}

Keywords: wild edible mushrooms, heavy metals, ICP-OES, trace elements

\section{Introduction}

The consumption of wild grown edible mushrooms is a worldwide custom. In Transylvania (Romania), there is a strong tradition of collecting wild edible fungi for eating and selling. Edibility assumes the absence of poisonous effects, a pleasant taste and aroma, and nevertheless the lack of concentrations of accumulated toxic elements dangerous to human health. However, this last aspect is often ignored by the collectors. Edible mushrooms constitute an important and widely appreciated part of the human nutrition because they are rich sources of 
proteins, fibres, vitamins, antioxidants, and minerals. Some elements are essential for living organisms, including chromium, cobalt, copper, iron, manganese, and zinc. Wild edible mushrooms constitute one of the main sources of these elements [1]. In the last few decades, the mapping of elemental content of mushrooms was at the centre of many chemical researches. These studies revealed specific elemental preferences of some mushrooms. For example, Macrolepiota procera accumulates mainly copper, but it can contain high amounts of $\mathrm{Mn}, \mathrm{Zn}, \mathrm{Cr}$, Ni, even $\mathrm{Cd}$ [2-5]; Chantarellus cibarius shows preference for $\mathrm{Mn}, \mathrm{Fe}$ [6]; Boletus edulis is known for its high content of $\mathrm{Se}, \mathrm{Ag}, \mathrm{Mn}$, and $\mathrm{Zn}[2,5,7]$ and Armillariella mellea for iron $[2,8]$. There are also some species, which are known for their low mineral content (Lactarius spp., Russula spp., Hypholoma fasciculare, Hydnum repandum) [2, 4, 7, 9-14]. Relying on several studies, a review paper highlighted the uneven distribution of the elements in the fruiting body of the mushrooms: the highest concentrations of metals can be found in the sporophore, followed by the other parts of the cap. The smallest metal content is found in the stipe [7].

Today it is also known the ability of some mushroom species to accumulate considerable amounts of metals as well as toxic elements with regard to the human organism, such as mercury, cadmium, lead, arsenic, or radionuclides [7, 15-19]. Near highly contaminated sites (smelters, metal mining, thermal power plants, industrial areas) and main roads, high content of heavy metals was detected in mature fruiting bodies of macrofungi $[8,9,20-22]$. A recent study on mushrooms growing in urban areas showed unusually elevated concentrations of $\mathrm{Cd}$ and $\mathrm{Pb}$ in the fruiting bodies [23].

These findings led us to hypothesize that a large city as Cluj-Napoca may have polluting effect over the mushrooms growing in the forest lying in the close vicinity of it. The city is the economic and cultural centre of Transylvania; in the last few years it has developed rapidly. With its increased road and air traffic and its expanding trends, it may pollute the Făget Forest, which is situated on the western and southern side of the city. Many inhabitants of Cluj-Napoca have the habit of going mushroom picking in the Făget for consumption purposes. The most popular species are Lactarius piperatus, Boletus edulis, Armillariella mellea, Macrolepiota procera, Russula spp., and Agaricus spp.

Our aim in this study was to determine the elemental composition of mushrooms growing in the Făget Forest, and thus to assess the health risk arisen from the long-term consumption of them. We also established the background levels of the elements in mushrooms by choosing an area considered unpolluted in the Apuseni Natural Park. 


\section{Materials and methods}

\section{Description of the sampling sites}

The Făget Forest is part of the Făgetul Clujului - Valea Morii Natura 2000 Network (ROSCI0074). It lies at an average altitude of $625 \mathrm{~m}$ and it consists dominantly of beech, less hornbeam, and spruce. The prevailing wind direction is from the west, the average annual temperature is $8.4^{\circ} \mathrm{C}$, and the average annual precipitation is $663 \mathrm{~mm}$ [24]. The control site consisted of the surroundings of Padiș, at an average altitude of $1,127 \mathrm{~m}$, situated in the Apuseni Natural Park, also part of the Natura 2000 Network (ROSCI 0002). The average annual temperature is $6.0^{\circ} \mathrm{C}$ and the average annual precipitation is $1,400 \mathrm{~mm}$ [24]. This site is covered with pinewoods; the dominant species is the Picea abies. In order to collect mushroom species whose habitat is the deciduous forest, we chose the beech forests at lower altitudes but close to Padiș.

\section{Sampling and sample proceeding}

A total number of 80 mushrooms of 16 species were collected from the Făget Forest and 60 mushrooms of 12 species from the Apuseni Natural Park in JulyOctober 2014. At least three individuals were picked up of the large-size species and at most 7 individuals of the small-size species. The samples were stored in plastic bags. The mushrooms were cleaned with tap water, and rinsed with distilled water. Further on, the caps and stipes were processed separately. They were dried at room temperature, and air-dried at $105^{\circ} \mathrm{C}$. The mashed and sieved powders, having the particle diameters less than $315 \mu \mathrm{m}$, were stored in plastic bottles until the digestion process. For the instrumental analysis, three samples were digested in parallel for each part (caps and stipes) of any mushroom species. The decomposition of organic matter was carried out at atmospheric pressure, using a digestion mixture of $5 \mathrm{~mL} 65 \% \mathrm{HNO}_{3}$ (Merck, suprapur) and $4 \mathrm{~mL} 30 \% \mathrm{H}_{2} \mathrm{O}_{2}$ (Merck, suprapur). The solution of nitric acid was added at room temperature to a mass of $0.2000 \mathrm{~g}$ sample, twelve hours prior to the heating process. The digestion was done at $90^{\circ} \mathrm{C}$ for 4 hours on an electric heating plate. The hydrogen-peroxide solution was added in two steps. The resulting digests were analysed with Agilent 5100 ICP-OES spectrometer, applying the simultaneous measuring technique. The calibration was performed with multi-elemental standards, and calibration curves were obtained for each element. A total of 20 elements (Ag, Al, Ba, Ca, Cd, Co, $\mathrm{Cr}, \mathrm{Cu}, \mathrm{Fe}, \mathrm{K}, \mathrm{Li}, \mathrm{Mg}, \mathrm{Mn}, \mathrm{Na}, \mathrm{P}, \mathrm{S}, \mathrm{Si}, \mathrm{Sr}, \mathrm{Zn}$ ) were quantified.

\section{Method of the risk assessment}

The risk assessment of the heavy metals to human health due to the consumption of the mushrooms can be evaluated by calculating the hazard quotient 
(HQ) for each metal of interest and the hazard index (HI), which is the sum of the hazard quotients $[25,26]$. The HQ is the ratio between the exposure and the reference dose $(E q$. 1). One can assume the existence of a risk for mushroom consumption when the HQ $>1$.

$$
H Q_{\text {metal }}=\frac{D I \cdot C_{\text {metal }}}{R_{f} D \cdot B W}
$$

where DI is the daily intake of mushrooms $\left(\mathrm{kg} \mathrm{day}^{-1}\right), C_{\text {metal }}$ is the concentration of the metal in the mushroom given for dry weight $\left(\mathrm{mg} \mathrm{kg}^{-1}\right), R_{f} D$ is the oral reference dose for the metal given for unit body weight $\left(\mathrm{mg} \mathrm{kg}^{-1}\right.$ day $\left.^{-1}\right)$, BW is the average human body weight $(\mathrm{kg})$. We used the $R_{f} D$ values published in the IRIS (Integrated Risk Information System) database, and they can be seen in Table 1 [27]. We used average body weights for different age-groups as reported by the guidance of the European Food Safety Authority [28]. The age-groups and BW values are given in Table 3.

The HI provides information about the joint health risk caused by the heavy metals when a specific mushroom is consumed. We calculated the hazard index as given by Eq. 2 .

$$
H I=H Q_{C d}+H Q_{C r}+H Q_{M n}+H Q_{N i}+H Q_{Z n}
$$

\section{Statistical analysis}

The statistical analyses were performed with $\mathrm{R}$ software (version 3.2.1, $\mathrm{R}$ Foundation for Statistical Computing) and Past software. We created a data matrix where the rows represented the caps and stipes of the mushroom species collected from the Făget Forest, while the columns contained the concentrations of the 20 studied elements. Before the statistical analysis, the concentration data were standardized, that is transforming the distributions of the variables in order to achieve distributions with zero means and standard deviations of 1.0. Thus, the differences in the concentration of major and minor elements, which were as huge as 4-6 orders of magnitude, were equilibrated. We studied the correlation between the elements with the Spearman rank correlation test. In order to compare the elemental composition of mushrooms grown in the selected geographical regions and the elemental distribution in the caps and stipes, we performed one-way ANOVA. Prior to the analysis, outliers were identified by Dixon Q-test for each element, and excluded from the dataset.

\section{Results and discussion}

The concentration means $(\mathrm{n}=3)$ for the elements quantified in the mushrooms from the Făget Forest are shown in Table 1 and Table 2. The Boletus edulis 
accumulated high amounts of $\mathrm{Ag}, \mathrm{S}$, and $\mathrm{Zn}$; the Macrolepiota procera accumulated $\mathrm{Cu}$; Lactarius volemus had the most elevated concentration of $\mathrm{Co}$; Russula emetica preferred Mn; Armillariella mellea and Chantarellus cibarius accumulated Cr. The cadmium content was the highest in the case of the Leccinum scabrum and Boletus edulis. The Lactarius deliciosus, Lactarius volemus, and Amanita rubescens species had the lowest mineral content.

The one-way ANOVA test revealed no significant differences between the elemental compositions of the mushrooms coming from the two selected areas. An exception was the $\mathrm{Ba}$, which had significantly $(\mathrm{p}=0.035$, Fisher's $\mathrm{F}=4.92$, $\mathrm{df}=$ 28) higher concentrations in the mushrooms from Făget than in the Apuseni Mountains. We also compared the elemental composition of caps and stipes of the 16 mushroom species using one-way ANOVA. Relying on the Fisher's F values, the $\mathrm{Ca}, \mathrm{Cr}, \mathrm{Li}, \mathrm{Ni}$, and $\mathrm{Zn}$ concentrations were significantly $(\mathrm{p}<0.05)$ higher in the caps than in the stipes of the fungi.

According to the Spearman rank correlation test (Table 4) carried out based on the concentrations of elements present in the mushroom caps and stipes from the Făget Forest, we found significant $(p<0.05)$ correlation between the alkalineearth metals (Ca-Sr, Ba-Sr, Ba-Ca), where rho was higher than 0.60. A strong correlation was also between the $\mathrm{Mn}$ with $\mathrm{Ca}, \mathrm{Ba}, \mathrm{Sr}$, and $\mathrm{P}$ (rho > 0.70). Magnesium was not correlated with these elements, but it had rho values between 0.41 and 0.53 with transitional metals such as $\mathrm{Ag}, \mathrm{Cd}, \mathrm{Cu}$, and $\mathrm{Fe}$. An interesting finding was the significant inverse correlation of sulphur with $\mathrm{Ca}, \mathrm{Ba}, \mathrm{Sr}$, and $\mathrm{Mn}$, and stronger positive correlation with $\mathrm{Ag}, \mathrm{Cd}, \mathrm{Zn}$, and $\mathrm{P}$. We also found significant correlations between other pairs of elements such as Fe-Mn, Fe-Cr, Fe-Na, K-Na, $\mathrm{K}-\mathrm{Al}$, Fe-Al, Cd-Zn, Cd-Ag, and $\mathrm{Cu}-\mathrm{Mg}$. Other studies on mushrooms found the same correlations between elements [4, 29].

In order to assess the contribution of some heavy metals to the health risk of mushroom consumption, we calculated the hazard quotients. The highest hazard quotient values were found for $\mathrm{Cd}(0.034-2.216)$, followed by $\mathrm{Zn}(0.014-0.201)$, but $\mathrm{Cr}(0.00001-0.00026)$ showed the lowest values. We evaluated the health risk of mushroom consumption concerning different age-groups relying on the hazard index (Table 3). Assuming that the mushroom season lasts 6 months (from May until October), in the calculus we reckoned with a weekly mushroom consumption of $1 \mathrm{~kg}$ (DI $=0.143 \mathrm{~kg} \mathrm{day}^{-1}$ fresh weight) for adults and adolescents beyond 14, and of $0.5 \mathrm{~kg}\left(\mathrm{DI}=0.071 \mathrm{~kg} \mathrm{day}^{-1}\right.$ fresh weight $)$ for children and teenagers. The average water content of the mushroom fruiting body was considered as $90 \%$ [2]. 
Table 1. The concentrations ( $\mathrm{mg} \mathrm{kg}^{-1}$, dry weight) of alkaline, alkaline-earth metals and non-metals in the mushrooms from the Făget Forest

\begin{tabular}{|c|c|c|c|c|c|c|c|c|c|c|c|}
\hline $\begin{array}{c}\text { Mushroom } \\
\text { species }\end{array}$ & Parts & $\mathrm{K}$ & $\mathrm{Na}$ & $\mathrm{Li}$ & $\mathrm{Ca}$ & $\mathrm{Mg}$ & $\mathrm{Ba}$ & $\mathrm{Sr}$ & $\mathrm{P}$ & S & $\mathrm{Si}$ \\
\hline Agaricus & cap & 27049 & 83.32 & 0.21 & 68.85 & 1065.1 & 2.53 & 0.55 & 10107 & 4886 & 81.83 \\
\hline campestris & stipe & 29924 & 102.28 & 0.25 & 158.96 & 645.5 & 1.04 & 0.62 & 5954 & 4418 & 121.60 \\
\hline Amanita & cap & 60512 & 509.09 & 0.21 & 445.12 & 1311.6 & 2.20 & 0.75 & 10234 & 8612 & 25.87 \\
\hline rubescens & stipe & 41674 & 580.04 & 0.25 & 277.59 & 492.3 & 1.08 & 0.50 & 5013 & 5998 & 15.36 \\
\hline Amillariella & cap & 44370 & 441.56 & 0.21 & 836.68 & 1078.1 & 1.79 & 0.96 & 6506 & 1925 & 38.94 \\
\hline mellea & stipe & 48270 & 428.33 & 0.02 & 703.69 & 699.8 & 6.36 & 1.50 & 1574 & 668 & 80.26 \\
\hline Boletus & cap & 33814 & 163.19 & 0.05 & 334.83 & 819.4 & 0.42 & 0.33 & 7821 & 17378 & 30.88 \\
\hline edulis & stipe & 25441 & 115.37 & 0.02 & 237.04 & 585.8 & 0.62 & 0.25 & 5052 & 16867 & 32.46 \\
\hline Chantarellus & cap & 33815 & 151.63 & 0.17 & 481.59 & 968.4 & 1.87 & 1.08 & 3676 & 868 & 49.95 \\
\hline cibarius & stipe & 34654 & 139.07 & 0.54 & 576.72 & 516.7 & 2.75 & 1.46 & 2060 & 488 & 35.97 \\
\hline Hydnum & cap & 46990 & 404.80 & 0.02 & 235.09 & 1115.8 & 1.96 & 0.50 & 7808 & 1913 & 45.35 \\
\hline repandum & stipe & 40230 & 380.31 & 0.38 & 481.65 & 788.3 & 5.24 & 0.96 & 5901 & 1426 & 24.28 \\
\hline Hypholoma & cap & 29577 & 317.49 & 0.37 & 448.35 & 947.7 & 1.37 & 0.67 & 6716 & 1943 & 27.97 \\
\hline fasciculare & stipe & 23506 & 194.70 & 0.17 & 328.75 & 421.4 & 2.04 & 0.79 & 2936 & 1023 & 59.97 \\
\hline Lactarius & cap & 21312 & 77.30 & 0.02 & 231.48 & 889.7 & 0.58 & 0.62 & 4265 & 1587 & 45.56 \\
\hline deliciosus & stipe & 15049 & 115.02 & 0.05 & 310.43 & 485.8 & 1.44 & 0.96 & 2407 & 1061 & 23.40 \\
\hline Lactarius & cap & 33823 & 172.81 & 0.25 & 248.26 & 802.5 & 1.12 & 0.37 & 4833 & 5479 & 48.37 \\
\hline piperatus & stipe & 43218 & 245.02 & 0.42 & 193.42 & 459.4 & 0.87 & 0.33 & 2529 & 3493 & 38.33 \\
\hline Lactarius & cap & 25340 & 161.61 & 0.09 & 296.08 & 612.7 & 1.67 & 0.62 & 3626 & 1495 & 71.03 \\
\hline volemus & stipe & 23430 & 209.87 & 0.26 & 294.78 & 373.8 & 1.25 & 0.58 & 1905 & 1136 & 61.65 \\
\hline Leccinum & cap & 37567 & 295.93 & 0.26 & 387.18 & 825.2 & 1.83 & 0.62 & 5704 & 3891 & 32.09 \\
\hline scabrum & stipe & 33132 & 202.61 & 0.14 & 417.59 & 313.1 & 5.11 & 0.87 & 2301 & 1717 & 59.23 \\
\hline Macrolepiota & cap & 31953 & 137.69 & 0.42 & 137.18 & 1250.0 & 1.87 & 0.33 & 12461 & 5301 & 28.18 \\
\hline procera & stipe & 38198 & 475.30 & 0.02 & 649.49 & 972.9 & 5.56 & 2.16 & 9545 & 5683 & 69.17 \\
\hline Russula & cap & 36915 & 207.33 & 0.02 & 275.99 & 781.4 & 2.66 & 0.75 & 4819 & 2162 & 31.79 \\
\hline alutacea & stipe & 27366 & 494.47 & 0.50 & 129.89 & 364.6 & 0.79 & 0.25 & 2146 & 1167 & 41.70 \\
\hline Russula & cap & 37968 & 284.18 & 0.17 & 601.78 & 868.1 & 5.69 & 1.33 & 4324 & 1356 & 49.65 \\
\hline emetica & stipe & 21798 & 248.88 & 0.53 & 793.20 & 810.9 & 6.68 & 1.47 & 6752 & 1698 & 49.97 \\
\hline Russula & cap & 40459 & 155.27 & 0.14 & 200.09 & 1030.4 & 0.87 & 0.42 & 5956 & 4007 & 24.69 \\
\hline virescens & stipe & 42346 & 210.27 & 0.66 & 327.66 & 547.2 & 1.33 & 0.66 & 3241 & 2001 & 36.86 \\
\hline Tricholoma & cap & 32438 & 262.65 & 0.62 & 378.45 & 1104.7 & 1.25 & 0.58 & 12068 & 2993 & 37.12 \\
\hline portentosum & stipe & 26396 & 377.16 & 0.25 & 963.06 & 531.41 & 3.57 & 1.79 & 2413 & 933 & 46.39 \\
\hline
\end{tabular}


Table 2. The concentrations ( $\mathrm{mg} \mathrm{kg}^{-1}$, dry weight) of minor and trace elements in the mushrooms from the Făget Forest

\begin{tabular}{|c|c|c|c|c|c|c|c|c|c|c|c|}
\hline $\begin{array}{l}\text { Mushroom } \\
\text { species }\end{array}$ & Parts & $\mathrm{Ag}$ & $\mathrm{Al}$ & $\mathrm{Cd}$ & $\mathrm{Co}$ & $\mathrm{Cr}$ & $\mathrm{Cu}$ & $\mathrm{Fe}$ & $\mathrm{Mn}$ & $\mathrm{Ni}$ & $\mathrm{Zn}$ \\
\hline Agaricus & cap & 2.82 & 23.74 & 0.76 & 0.24 & 0.439 & 64.01 & 88.47 & 8.2 & 0.33 & 115.56 \\
\hline campestris & stipe & 11.76 & 52.13 & 0.61 & 0.18 & 0.548 & 73.79 & 80.22 & 10.1 & 0.34 & 60.61 \\
\hline Amanita & cap & 0.50 & 115.76 & 0.91 & 0.25 & 0.166 & 41.48 & 101.77 & 26.5 & 0.75 & 137.89 \\
\hline rubescens & stipe & 0.11 & 55.50 & 0.50 & 0.37 & 0.075 & 18.85 & 44.43 & 9.8 & 0.67 & 78.51 \\
\hline Amillariella & cap & 0.54 & 112.92 & 2.96 & 0.12 & 1.915 & 14.95 & 102.27 & 26.5 & 0.50 & 57.38 \\
\hline mellea & stipe & 0.37 & 198.61 & 0.71 & 0.12 & 0.416 & 7.89 & 208.28 & 63.1 & 0.25 & 20.15 \\
\hline Boletus & cap & 14.61 & 14.69 & 4.62 & 0.25 & 0.075 & 30.58 & 50.06 & 8.7 & 0.62 & 163.21 \\
\hline edulis & stipe & 7.86 & 10.39 & 2.58 & 0.25 & 0.075 & 17.71 & 38.48 & 6.6 & 0.33 & 89.11 \\
\hline Chantarellus & cap & 0.37 & 70.44 & 0.50 & 0.12 & 1.704 & 45.92 & 94.75 & 16.1 & 0.33 & 69.15 \\
\hline cibarius & stipe & 0.12 & 36.93 & 0.17 & 0.12 & 1.831 & 20.69 & 35.26 & 19.5 & 0.79 & 34.05 \\
\hline Hydnum & cap & 0.58 & 133.72 & 0.62 & 0.12 & 0.375 & 35.32 & 218.26 & 23.7 & 0.25 & 52.43 \\
\hline repandum & stipe & 1.71 & 53.99 & 0.29 & 0.12 & 0.191 & 31.03 & 86.95 & 54.0 & 5.23 & 39.80 \\
\hline Hypholoma & cap & 5.54 & 26.14 & 1.00 & 0.12 & 0.075 & 32.59 & 128.13 & 19.9 & 0.25 & 64.15 \\
\hline fasciculare & stipe & 3.71 & 35.69 & 0.37 & 0.12 & 0.075 & 18.45 & 84.71 & 29.1 & 0.25 & 38.94 \\
\hline Lactarius & cap & 0.25 & 52.41 & 1.62 & 0.12 & 0.091 & 7.44 & 80.17 & 4.4 & 0.25 & 70.77 \\
\hline deliciosus & stipe & 0.12 & 31.32 & 0.75 & 0.12 & 0.075 & 8.23 & 32.97 & 3.7 & 0.37 & 56.72 \\
\hline Lactarius & cap & 6.03 & 34.01 & 2.70 & 0.29 & 0.091 & 64.47 & 52.55 & 8.3 & 0.29 & 116.44 \\
\hline piperatus & stipe & 1.21 & 21.32 & 0.87 & 0.75 & 0.191 & 38.54 & 29.89 & 4.3 & 0.25 & 71.08 \\
\hline Lactarius & cap & 0.42 & 25.35 & 0.87 & 8.78 & 0.125 & 65.15 & 37.43 & 22.8 & 2.29 & 61.12 \\
\hline volemus & stipe & 0.22 & 53.67 & 0.33 & 5.32 & 0.150 & 40.21 & 58.16 & 15.0 & 1.00 & 42.79 \\
\hline Leccinum & cap & 0.46 & 46.60 & 10.85 & 0.12 & 0.091 & 27.89 & 85.63 & 27.2 & 0.25 & 110.70 \\
\hline scabrum & stipe & 0.12 & 60.23 & 4.36 & 0.12 & 0.075 & 11.59 & 46.27 & 44.0 & 0.37 & 47.85 \\
\hline Macrolepiota & cap & 7.78 & 40.84 & 2.54 & 0.12 & 0.192 & 147.30 & 76.06 & 13.4 & 0.25 & 74.15 \\
\hline procera & stipe & 6.64 & 137.71 & 1.41 & 0.29 & 0.091 & 148.04 & 96.40 & 24.2 & 0.25 & 67.67 \\
\hline Russula & cap & 0.66 & 37.78 & 1.41 & 0.12 & 0.075 & 36.66 & 76.27 & 23.5 & 0.83 & 85.56 \\
\hline alutacea & stipe & 0.11 & 24.30 & 0.37 & 0.50 & 0.075 & 22.38 & 92.94 & 10.0 & 0.75 & 295.22 \\
\hline Russula & cap & 1.12 & 22.97 & 1.12 & 0.25 & 0.075 & 38.63 & 56.46 & 67.0 & 0.25 & 83.42 \\
\hline emetica & stipe & 4.11 & 57.73 & 0.51 & 0.14 & 0.217 & 44.43 & 90.10 & 82.0 & 7.93 & 46.55 \\
\hline Russula & cap & 0.46 & 65.94 & 0.87 & 0.81 & 0.091 & 42.01 & 45.41 & 14.5 & 6.27 & 94.40 \\
\hline virescens & stipe & 0.25 & 98.64 & 0.25 & 0.50 & 0.150 & 23.93 & 47.39 & 13.0 & 2.16 & 74.78 \\
\hline Tricholoma & cap & 4.28 & 43.13 & 1.71 & 0.12 & 0.075 & 64.77 & 73.71 & 19.1 & 0.37 & 81.20 \\
\hline portentosum & stipe & 0.21 & 25.98 & 0.46 & 0.17 & 0.075 & 30.59 & 50.17 & 44.2 & 4.07 & 65.38 \\
\hline
\end{tabular}

For adults and adolescents, only two species, the Boletus edulis and Leccinum scabrum, pose a health risk when the mushroom is regularly consumed. Children under 10 years of age and toddlers are exposed to a greater degree with regard to several species. The mushrooms with the highest risk levels were the Boletus edulis, Leccinum scabrum, Russulacea spp., Lactarius spp., and Armillariella mellea. However, the mushrooms with the lowest HI values were: Chantarellus cibarius, Hydnum repandum, Agaricus campestris, and Lactarius volemus. 
Table 3. The hazard index values for the caps of mushrooms grown in the Făget Forest

\begin{tabular}{lccccc}
\hline \multicolumn{7}{c}{ Hazard index (HI) } & & & \\
\hline Age-groups & $1-3$ & $3-10$ & $10-14$ & $14-18$ & adult \\
\hline Average body weight $(\mathrm{kg})^{\#}$ & 12 & 23 & 43 & 61 & 70 \\
\hline Agaricus campestris & 0.72 & 0.38 & 0.20 & 0.29 & 0.25 \\
Amanita rubescens & 0.95 & 0.49 & 0.26 & 0.38 & 0.33 \\
Armillariella mellea & $1.99^{*}$ & $1.04^{*}$ & 0.56 & 0.79 & 0.69 \\
Boletus edulis & $3.11^{*}$ & $1.62^{*}$ & 0.87 & $1.23^{*}$ & $1.07^{*}$ \\
Chantarellus cibarius & 0.51 & 0.27 & 0.14 & 0.20 & 0.18 \\
Hydnum repandum & 0.58 & 0.30 & 0.16 & 0.23 & 0.20 \\
Hypholoma fasciculare & 0.81 & 0.42 & 0.23 & 0.32 & 0.28 \\
Lactarius deliciosus & $1.12^{*}$ & 0.59 & 0.31 & 0.45 & 0.39 \\
Lactarius piperatus & $1.87^{*}$ & 0.98 & 0.52 & 0.74 & 0.65 \\
Lactarius volemus & 0.80 & 0.42 & 0.22 & 0.32 & 0.28 \\
Leccinum scabrum & $6.76^{*}$ & $3,53^{*}$ & $1.89^{*}$ & $2.68^{*}$ & $2.33^{*}$ \\
Macrolepiota procera & $1.71^{*}$ & 0.89 & 0.48 & 0.68 & 0.59 \\
Russula alutacea & $1.13^{*}$ & 0.59 & 0.31 & 0.45 & 0.39 \\
Russula emetic & $1.12^{*}$ & 0.58 & 0.31 & 0.44 & 0.39 \\
Russula virescens & 0.95 & 0.50 & 0.26 & 0.38 & 0.33 \\
Tricholoma portentosum & $1.26^{*}$ & 0.66 & 0.35 & 0.50 & 0.44 \\
\hline Source Eurropan Food Safety Authority & Journat & 241 & &
\end{tabular}

"Source: European Food Safety Authority Journal [24]

\section{Conclusions}

The comparative study of the wild edible mushrooms from the Făget Forest and the Apuseni Mountains showed no significant differences in the concentration of 19 macro-, micro-, and trace elements. Only barium was significantly higher in the mushrooms grown in the Făget. The hazard index values were relatively low. Two species (Boletus edulis and Leccinum scabrum) may be considered to have slightly elevated risk levels when they are consumed regularly. The element with the highest contribution to the hazard index was the Cd. However, other studies revealed the cadmium-accumulating capacity of these species $[2,6]$. We can conclude that the polluting effect of Cluj-Napoca as a city with high traffic and continuous expanding trends was not detectable in the wild-growing mushrooms. 


\section{References}

[1] Kalač, P. (2013), A review of chemical composition and nutritional value of wild-growing and cultivated mushrooms. Journal of the Science of Food and Agriculture 93, 209-18.

[2] Kalač, P. (2010), Trace element contents in European species of wild growing mushrooms: A review for the period 2000-2009, Food Chemistry 122, 2-15.

[3] Kułdo, E., Jarzyńska, G., Gucia, M., Falandysz, J. (2014), Mineral constituents of edible parasol mushroom Macrolepiota procera (Scop. ex Fr.) Sing and soils beneath its fruiting bodies collected from a rural forest area. Chemical papers 68, 484-492.

[4] Severoglu, Z., Sumer, S., Yalcin, B., Leblebici, Z., Aksoy, A. (2013), Trace metal levels in edible wild fungi. International Journal of Science and Technology 10, 295-304.

[5] Giannacini, G., Betti, L., Palego, L., Mascia, G., Schmid, L., Lanza, M., Mela, A., Fabbrini, L., Biondi, L., Lucacchini, A. (2012), The trace element content of top-soil and wild edible mushroom samples collected in Tuscany, Italy. Environmental Monitoring and Assessment 184, 7579-7595.

[6] Sesli, E., Tuzen, M., Soylak, M. (2008), Evaluation of trace metal contents of some wild edible mushrooms from Black sea region, Turkey. Journal of Hazardous Materials 160, 462-567.

[7] Kalač, P., Svoboda, L. (2000), A review of trace element concentrations in edible mushrooms. Food Chemistry 69, 273-281.

[8] Radulescu, C., Stihi, C., Busuioc, G., Gheboianu, A. I., Popescu, I. V. (2010), Studies concerning heavy metals bioaccumulation of wild edible mushrooms from industrial area by using spectrometric techniques. Bulletin of Environmental Contamination and Toxicology 84, 641-646.

[9] Çayir, A., Coşkun, M., Coşkun, M. (2010), The heavy metal content of wild edible mushroom samples collected in Canakkale Province, Turkey. Biological Trace Element Research 134, 212-219.

[10] Chen, X. H., Zhou, H. B. Qiu, G. Z. (2009), Analysis of several heavy metals in wild edible mushrooms from regions of China. Bulletin of Environmental Contamination and Toxicology $83,280-285$.

[11] Tüzen, M., Özdemir, M. Demirbaş, A. (1998), Study of heavy metals in some cultivated and uncultivated mushrooms of Turkish origin. Food Chemistry 63, 247-251.

[12] Alonso, J., García, M. A., Pérez-López, M., Melgar, M. J. (2003), The concentration and bioaccumulation factor of copper and zinc in edible mushrooms. Archives of Environmental Contamination and Toxicology 44, 180-188.

[13] Demirbaş, A. (2001), Concentration of 21 metals in 18 species of mushrooms growing in the East Black Sea region. Food Chemistry 75, 453-457.

[14] Busuioc, G., Elekes C. C., Stihi, C., Iordache S., Ciulei, S. C. (2011), The bioaccumulation and translocation of $\mathrm{Fe}, \mathrm{Zn}$, and $\mathrm{Cu}$ in species of mushrooms from Russula genus. Environmental Science and Pollution Research 18, 890-896.

[15] Falandysz, J., Drewnowska, M., Jarzyńska, G., Zhang, D., Zhang, Y., Wang, J. (2012), Mineral constituents in common chanterelles and soils collected from a high mountain and lowland sites in Poland. Journal of Mountain Science 9, 697-705.

[16] García, M. A., Alonso, J., Fernández, M. I., Melgar, M. J. (1998), Lead content in edible wild mushrooms in northwest Spain as indicator of environmental contamination. Archives of Environmental Contamination and Toxicology 34, 330-335.

[17] Krichner, G., Daillant, O. (1998), Accumulation of ${ }^{210} \mathrm{~Pb}$ and ${ }^{226} \mathrm{Ra}$ and radioactive cesium by fungi. Science of the Total Environment 222, 63-70.

[18] Vetter, J. (2004), Arsenic content of some edible mushroom species. European Food Research and Technology 219, 71-74. 
[19] Cocchi, L., Vescovi, L., Petrini, L. E., Petrini, O. (2006), Heavy metals in edible mushrooms in Italy. Food Chemistry 98, 277-284.

[20] Petkovšek, S. A. S., Pokorny, B. (2013), Lead and cadmium in mushrooms from the vicinity of two large emission sources in Slovenia. Science of the Total Environment 443, 944-954.

[21] Olumuyiwa, S. F., Oluwatoyin, O. A., Olanrewaja O., Steve R. A. (2007), Chemical composition and toxic trace element composition of some Nigerian edible wild mushroom. International Journal of Science and Technology 43, 24-29.

[22] Svoboda, L., Zimmermannivá, K., Kalač, P. (2000), Concentrations of mercury, cadmium, lead and copper in fruiting bodies of edible mushrooms in an emission area of a copper smelter and a mercury smelter. The Science of the Total Environment 246, 61-67.

[23] Schlecht, M. T., Säumel, I. (2015), Wild growing mushrooms for the Edible City? Cadmium and lead content in edible mushrooms harvested within the urban agglomeration of Berlin, Germany. Environmental Pollution 204, 298-305.

[24] Brânzan, T. (2013), Catalogul habitatelor, speciilor și siturilor Natura 2000 în România. Ed. Fundația Centrul Naţional pentru Dezvoltare Durabilă, București.

[25] Guerra, F., Trevizam, A. R., Muraoka, T., Marcante, N. C., Canniatti-Brazaca, S. G. (2011), Heavy metals in vegetables and potential risk for human health. Scientia Agricola 69, 54-60.

[26] US EPA (2013), Reference dose (RfD): Description and use in health risk assessments, Background Document 1A, Integrated risk information system (IRIS); United States Environmental Protection Agency: Washington, DC, 15 March 2013; http://www epa.gov/iris/rfd.htm.

[27] IRIS, USEPA, http://cfpub.epa.gov/ncea/iris/index.cfm?fuseaction=iris.showSubstance List

[28] EFSA Journal (2012), Guidance on selected default values to be used by the EFSA Scientific Committee, Scientific Panels and Units in the absence of actual measured. European Food Safety Authority Journal 10, 2579.

[29] Wang, X. M., Zhang, J., Li, T., Wang, Y. Z., Liu, H. G. (2015), Content and bioaccumulation of nine mineral elements in ten mushroom species of the genus Boletus. Journal of Analytical Methods in Chemistry 2015, 1-7. 